\title{
O MANIFESTO DA TRANSCONSTITUCIONALIDADE PARA PRESERVAÇÃO DO MEIO AMBIENTE
}

\author{
THE MANIFESTO OF TRANSCONSTITUTIONALITY FOR PRESERVATION OF \\ THE ENVIRONMENT
}

\author{
EL MANIFIESTO DE LA TRANSCONSTITUCIONALIDAD PARA LA \\ PRESERVACIÓN DEL MEDIO AMBIENTE
}

\author{
https://orcid org/0000-0002-6971-1412 / http://lattes.cnpg br/3283434447576859 / leonel rochaDicloud.com \\ LEONEL SEVERO ROCHA \\ Universidade do Vale do Rio dos Sinos (UNISINOS). \\ São Leopoldo, RS, Brasil.
}

Julia Francieli NeVES de SCherbaum

https://orcid.org/0000-0001-5496-9085 / http://lattes.cnpq.br/7961191624332149 /julianeves15@hotmail.com Universidade do Vale do Rio dos Sinos (UNISINOS). São Leopoldo, RS, Brasil.

\begin{abstract}
RESUMO
0 artigo inscreve-se no campo dos estudos da sociologia constitucional para efetivação do direito ambiental ecologicamente equilibrado à luz do transconstitucionalismo, tem como objetivo problematizar o fenômeno do transconstitucionalismo e seus reflexos na proteção ambiental. Para tanto, apresenta uma síntese dos crimes ambientais e a cooperação entre os estados. Por fim analisa-se a implantação da proteção ambiental a cerca da atuação do transconstitucionalismo, especialmente, as posições de C. Thornhill, G. Teubner e L. S. Rocha. Quanto à Metodologia, é a matriz pragmático-sistêmica, evidenciando sua influência nos estudos atuais acerca da sociologia do constitucionalismo. Tal percurso possibilita constatar ao direito ambiental a necessária transição entre perspectivas teóricas no atual cenário, propõem que seja a partir da elaboração de um transconstitucionalismo, visando o aproveitamento das experiências de ordens jurídicas externas e a cooperação entre os estados, bem como a informação e participação da coletividade de cunho ambiental, que são essenciais ao aperfeiçoamento de uma cultura global de preservação ambiental.
\end{abstract}

Palavras-chave: Direito ambiental; Sociologia Constitucional; Transconstitucionalismo.

\begin{abstract}
The article is part of the study of constitutional sociology for the realization of ecologically balanced environmental law in the light of transconstitutionalism, aims to problematize the phenomenon of transconstitutionalism and its impact on environmental protection. To do so, it presents a summary of environmental crimes and cooperation between states. Finally, we analyze the implementation of environmental protection around the performance of the transconstitutionalism, especially the positions of C. Thornhill, G. Teubner and L. S. Rocha. As for the Methodology, it is the pragmatic-systemic matrix, evidencing its influence in the current studies on the sociology of constitutionalism. This course makes it possible to verify to environmental law the necessary transition between theoretical perspectives in the current scenario, propose that it be based on the elaboration of a transconstitutionalism, aiming at the exploitation of the experiences of external legal orders and cooperation among the states, as well as information and participation of environmental collectivity, which are essential to the improvement of a global culture of environmental preservation.
\end{abstract}

Keywords: Environmental law; Constitutional Sociology; Transconstitutionalism. 


\section{RESUMEN}

El artículo se inscribe en el campo de los estudios de la sociología constitucional para la efectividad del derecho ambiental ecológicamente equilibrado a la luz del transconstitucionalismo, tiene como objetivo problematizar el fenómeno del transconstitucionalismo y sus reflejos en la protección ambiental. Para ello, presenta una síntesis de los crímenes ambientales y la cooperación entre los estados. Por último se analiza la implantación de la protección ambiental a cerca de la actuación del transconstitucionalismo, especialmente, las posiciones de C. Thornhill, G. Teubner y L. S. Rocha. En cuanto a la Metodología, es la matriz pragmática-sistémica, evidenciando su influencia en los estudios actuales acerca de la sociología del constitucionalismo. Este camino permite constatar al derecho ambiental la necesaria transición entre perspectivas teóricas en el actual escenario, proponen que sea a partir de la elaboración de un transconstitucionalismo, visando el aprovechamiento de las experiencias de órdenes jurídicas externas y la cooperación entre los estados, así como la información y participación de la colectividad de cuño ambiental, que son esenciales para el perfeccionamiento de una cultura global de preservación ambiental.

Palabras clave: Derecho ambiental; Sociología Constitucional; Transconstitucionalismo.

\section{SUMÁRIO}

INTRODUÇÃO; 1 ASPECTOS SOBRE A CRISE AMBIENTAL NA SOCIEDADE DO RISCO; 2 A PROTEÇÃO PENAL AMBIENTAL E A COOPERAÇÃO ENTRE OS ESTADOS; 3 A IMPLANTAÇÃO DA PROTEÇÃO AMBIENTAL POR MEIO DO TRANSCONSTITUCIONALISMO; CONCLUSÃO; REFERENCIAS.

\section{INTRODUÇÃO}

Devido aos problemas decorrentes da degradação ambiental que têm assumido alcance global, tornando premente a cooperação entre os Estados com ideal de desenvolvimento sustentável e a proteção ambiental sadia, impedindo também novos danos ao meio ambiente, visando à exploração consciente do ecossistema frente à geração presente em favor da manutenção da qualidade de vida, como meio de resguardar as gerações futuras. Diante disso, o Estado e o Direito precisam se transformar para atender aos efeitos emergenciais da crise ecológica em prol da sobrevivência da humanidade, justificando a necessidade de um Estado de Direito Ambiental.

Assim, o que se pretende demonstrar nas linhas seguintes é que os deveres a que o Estado brasileiro se impôs por meio da Lei dos Crimes Ambientais devem ser interpretados à luz das regras do contemporâneo Direito Internacional Público, especialmente na sua vertente ambiental conhecida como Direito Ambiental Internacional ${ }^{1}$. Portanto o desafio é a garantia de respeito a essas esferas de regulamentação privada, a qual deve ser buscada não somente na organização interna, mas também nos apoios externos de outros sistemas, preparando suas estruturas dogmáticas para essa realidade sob a perspectiva da justiça discursiva

${ }^{1}$ MAZZUOLI, Valério de Oliveira. Curso de direito internacional público. 5. ed. rev., atual. e ampl. São Paulo: Ed. RT, 2011. p. 977-984. 
policontextural ${ }^{2}$, contemplando uma visão sistêmica do meio social. A Policontexturalidade é uma metáfora re-utilizada (Luhmann, Teubner) como critério de investigação da fragmentação do sentido na pós-modernidade, sendo uma interessante perspectiva para a análise do Pluralismo Jurídico Transnacional. Portanto, a análise do meio ambiente global ocorre como forma de regulação e acoplamento ao Direito na sociedade, que será sob a ótica das contribuições de Gunther Teubner ${ }^{3}$, a partir de suas observações criteriosas sobre as obras de Luhmann a respeito da matriz pragmático-sistêmica autopoiética.

No intuito de analisar o âmbito da questão ambiental na Globalização funcionalmente diferenciada, o que Luhmann define como sociedade mundial, diante da insuficiência da teoria tradicional do direito fazem-se necessárias novas leituras da teoria constitucional ${ }^{4}$. Trata-se da ampliação da existência de novos atores no contexto mundial, bem como para o deslocamento dos centros de tomada de decisão do âmbito limitado dos Estados Nacionais e Internacionais.

Nesse sentido, Chris Thornhill realiza um estudo sobre a Constituição Global e suas características. Descreve que é amplamente diagnosticado que a sociedade global contemporânea testemunha um processo de globalização jurídica e, consequentemente, o surgimento de novas formas de constitucionalidade ${ }^{5}$. 0 problema investigado é analisar, qual 0 fenômeno do transconstitucionalismo e seus reflexos na proteção ambiental?

Observa-se a importância desta pesquisa, que foi resultado de estudos do Projeto de Produtividade em Pesquisa da Universidade do Vale do Rio dos Sinos- UNISINOS, sobre Teoria do Direito. Este estudo ressalta a efetivação do direito ambiental ecologicamente equilibrado à luz do transconstitucionalismo, ramo de intersecção entre sociologia sistêmica e teoria constitucional. Nessa transição, necessário se faz atentar para as diferentes matrizes da teoria jurídica, pontos de partida para observar a teoria do Direito ${ }^{6}$. Rocha ressalta a necessária transição da matriz analítica, de cunho normativista, para uma perspectiva pragmáticosistêmica, com ênfase na organização ${ }^{7}$.

2 TEUBNER, Günther. Após a privatização: conflitos de discursos no direito privado constante da obra Direito, Sistema e Policontexturalidade. Piracicaba: Unimep, 2005.

3 TEUBNER, Gunther. Direito, sistema e policontexturalidade. Piracicaba: Universidade Metodista de Piracicaba - Campus de Taquaral, 2005, p. 284.

${ }^{4}$ LUHMANN, Niklas. La sociedad de la sociedad. Traducción de Javier Torres Nafarrate. México: Herder, 2007.

${ }^{5}$ THORNHILL, Chris. A Sociology of Transnational Constitutions: Social Foundations of the Post-National Legal Structure. Cambridge University Press. 2016.

${ }^{6}$ ROCHA, Leonel Severo. Epistemologia jurídica e democracia. 2. ed. São Leopoldo: Unisinos, 2005.

7 ROCHA, Leonel Severo. Epistemologia jurídica: revisitando as três matrizes. Revista de Estudos Constitucionais, Hermenêutica e Teoria do Direito (RECHTD). São Leopoldo, RS, v. 5, n. 2, jul./dez. 2013. Disponível em: Acesso em: 29 mar. 2018. 
Esta pesquisa tem por objetivo tratar do transconstitucionalismo e o respaldo ambiental, entre ordens jurídicas e sua aplicabilidade para fins do desenvolvimento sustentável e da proteção ambiental advindos da cooperação entre os Estados. Analisam-se também os institutos que visam a preservação do meio ambiente, tal como delineado nos artigos 77 e 78 da Lei 9.605 , de 12 de fevereiro de $1998^{8}$, tendo em vista que a conduta humana negligente frente aos recursos naturais, resultou na crise ambiental, o qual fez com que a proteção do meio ambiente encontre respaldo na aplicabilidade jurídica e constitucional.

Para se chegar a esse desiderato, o artigo está dividido e três itens, primeiramente serão investigados como a crise ambiental na sociedade do risco afeta o meio ambiente sadio e exige que o desenvolvimento sustentável se faça de maneira efetiva, indicando um mecanismo inovador na conjuntura global, tal qual se demonstra o transconstitucionalismo. No segundo item será estudada a proteção penal do meio ambiente e a cooperação entre os estados. Por fim, será analisada a implantação da proteção ambiental e do desenvolvimento sustentável através do transconstitucionalismo.

A metodologia a ser utilizada é a matriz teórica sistêmica que se dá pela abordagem sociológica, tanto conceitual quanto empírica dos sistemas jurídico. A observação da sociedade enquanto sistema apresenta vantagens porque permite a análise da sua complexidade por meio da reconstrução do saber jurídico e da práxis judicial, de um ponto de vista interdisciplinar, para o enfrentamento das incertezas da sociedade contemporânea em uma perspectiva evolutiva e construtiva9. Segundo Leonel Severo Rocha, na mesma linha de Lhumann "somente a comunicação pode produzir comunicação” ${ }^{10}$, portanto ela se faz cada vez mais necessária, na

\footnotetext{
${ }^{8}$ Assim dispõem os artigos referidos: "Art. 77. Resguardados a soberania nacional, a ordem pública e os bons costumes, o Governo brasileiro prestará, no que concerne ao meio ambiente, a necessária cooperação a outro país, sem qualquer ônus, quando solicitado para: I - produção de prova; II - exame de objetos e lugares; III - informações sobre pessoas e coisas; IV - presença temporária da pessoa presa, cujas declarações tenham relevância para a decisão de uma causa; $V$ - outras formas de assistência permitidas pela legislação em vigor ou pelos tratados de que o Brasil seja parte. $\S 1^{\circ} \mathrm{A}$ solicitação de que trata este artigo será dirigida ao Ministério da Justiça, que a remeterá, quando necessário, ao órgão judiciário competente para decidir a seu respeito, ou a encaminhará à autoridade capaz de atendê-la. $\S 2^{\circ} \mathrm{A}$ solicitação deverá conter: I - o nome e a qualificação da autoridade solicitante; II - o objeto e o motivo de sua formulação; III - a descrição sumária do procedimento em curso no país solicitante; IV - a especificação da assistência solicitada; $\vee$ - a documentação indispensável ao seu esclarecimento, quando for o caso. Art. 78. Para a consecução dos fins visados nesta Lei e especialmente para a reciprocidade da cooperação internacional, deve ser mantido sistema de comunicações apto a facilitar o intercâmbio rápido e seguro de informações com órgãos de outros países".

9 ROCHA, Leonel Severo. Direito ambiental e autopoiese. / Leonel Severo Rocha, Francisco Carlos Duarte./ Curitiba: Juruá, 2012,

${ }_{10}$ ROCHA, Leonel Severo. Direito ambiental e autopoiese. / Leonel Severo Rocha, Francisco Carlos Duarte./ Curitiba: Juruá, 2012, p.13.
} 
busca de interdisciplinaridade de todas as áreas do conhecimento. Desta forma, procura-se adotar, neste artigo, a Teoria Sistêmica como uma maneira sofisticada de comunicação.

\section{ASPECTOS SOBRE A CRISE AMBIENTAL NA SOCIEDADE DE RISCO}

Denota-se alguns aspectos em torno da crise ambiental e da sociedade de risco, o estudo do risco ecológico recebeu especial atenção pelo Direito e pela Sociologia como forma de tentar minimizar os impactos da crise ambiental. Como consequência, surge a teoria da sociedade de risco, fundamentada inicialmente por Ulrich Beck, em meados da década de 1980, a partir da sua obra "A sociedade de risco". Segundo Beck, a sociedade de risco "designa uma fase no desenvolvimento da sociedade moderna, em que os riscos sociais, políticos, econômicos e individuais tendem cada vez mais a escapar das instituições para o controle e a proteção da sociedade industrial"11.

Desta forma, passou-se a discutir qual seria o risco aceitável, em virtude do desenvolvimento industrial provado pela modernidade, possibilitando uma discussão do modo complexo da relação entre o homem com o meio ambiente. Percebe-se a necessidade de precisar não só um diferente modelo econômico, mas uma nova era de modelos atenta à problemática ambiental. Acerca do tema, observa Rocha:

[...] Na Sociedade Industrial, pode-se dizer que há certa previsibilidade das consequências dos processos produtivos capitalistas no sistema econômico. Contudo, na Sociedade de Risco (que não deixa de se tratar de uma Sociedade Industrial, porém, potencializada desenvolvimento tecnológico-científico), há um incremento na incerteza quando às consequências das atividades e tecnologias empregadas nos processos econômicos $[\ldots]^{12}$.

Observa-se, que a sociedade de risco na era industrial era previsível, entretanto atualmente revelam-se, como um modelo teórico que marca a falência da modernidade, emergindo um período pós-moderno, na medida em que as ameaças produzidas ao longo da sociedade industrial começam a tomar forma. Os pilares da concepção moderna de civilização já

\footnotetext{
11 BECK, Ulrich. A reinvenção da política: rumo a uma teoria da modernização reflexiva. In: BECK, Ulrich; GIDDENS, Anthony; LASH, Scott. Modernização reflexiva: política, tradição e estética na ordem social moderna. São Paulo: UNESP, 1997. p. 25.

12 ROCHA, Leonel Severo. Uma nova forma para a observação do direito globalizado: policontextualidade jurídica e estado ambiental. In: CARLIN, Volnei Ivo (Org.). Grandes temas de direito administrativo: homenagem ao Professor Paulo Henrique Blasi. Campinas: Millenium, 2009. p. 527.
} 
não conseguem mais explicar os desenvolvimentos da ciência e da sociedade. Trata-se de uma crise de paradigma ${ }^{13}$.

Contudo, o Direito não se constrói para si mesmo ou para uma ordem social e política abstrata. Ele deve se interessar pelo homem concreto, pelas diferentes realidades humanas, permanentes e mutantes, que servem de elemento para a História Universal. A justiça legal e a justiça moral dão-se as mãos e se fundem para construir um mundo saudável e justo ${ }^{14}$.

Nesse sentido, a Sociedade Industrial, pode-se dizer que há certa previsibilidade das consequências dos processos produtivos capitalistas no sistema econômico. Contudo, na Sociedade de Risco que não deixa de se tratar de uma Sociedade Pós-Industrial ${ }^{15}$, porém, potencializada pelo desenvolvimento tecnológico e científico, há um incremento na incerteza quando às consequências das atividades e tecnologias empregadas nos processos econômicos ${ }^{16}$.

A revolução causada pela globalização e aproximação dos mercados com ampliação do comércio que passa a ser seguido em escala internacional exige da empresa uma postura compromissada com a proteção ambiental. Em contrapartida, estes produtos esta passando por um processo de aceitação em âmbito internacional, principalmente no mercado europeu, e a certificação voltada para testar o respeito da norma de proteção ambiental é um diferencial para vender aos consumidores cada vez mais cientes e exigentes.

Segundo Niklas Luhmann a Sociedade Mundial é paradoxalmente, constituída por sistemas parciais diferenciados funcionalmente, os quais, no entanto, detém na comunicação o seu elemento último para a auto-reprodução do sistema. Ou seja, a partir da universalização da comunicação, como unidade de operação, que o sistema social global se diferencia do ambiente (não sistema $)^{17}$. A existência de uma Sociedade Contemporânea em nível globalizado, onde dimensões comunicacionais são mundializadas, emerge a partir do momento histórico em que a comunicação torna-se universal. Günther Teubner esclarece que o fenômeno da globalização, como é experimentado hoje, significa um deslocamento de proeminência no princípio primário

\footnotetext{
${ }^{13}$ ROCHA, Leonel Severo. Uma nova forma para a observação do direito globalizado: policontextualidade jurídica e estado ambiental. In: CARLIN, Volnei Ivo (Org.). Grandes temas de direito administrativo: homenagem ao Professor Paulo Henrique Blasi. Campinas: Millenium, 2009. p. 527.

${ }^{14}$ MILARÉ, E. Direito do ambiente: doutrina, jurisprudência e glossário. 6. ed. São Paulo: Revistas dos Tribunais, 2009. p. 141.

${ }^{15}$ BELL, Daniel. O Advento da Sociedade Pós-Industrial. São Paulo. Cultrix. 1974.

${ }^{16}$ ROCHA, Leonel Severo. Uma nova forma para a observação do direito globalizado: policontextualidade jurídica e estado ambiental. In: CARLIN, Volnei Ivo (Org.). Grandes temas de direito administrativo: homenagem ao Professor Paulo Henrique Blasi. Campinas: Millenium, 2009. p. 527.

${ }^{17}$ LUHMANN, Niklas. Sistemas sociales: lineamentos para una teoria general. México: Alianza Editorial/Universidad, 1991.p. 409
} 
da diferenciação diretriz: um deslocamento da diferenciação territorial para a funcional em nível mundial ${ }^{18}$.

Por outro lado, percebe-se a importância da biodiversidade, e que sem a sua preservação, não haverá garantia de sobrevivência da maioria das espécies. Foi difícil de perceber que os recursos naturais não são inesgotáveis, e que todas as atitudes que atingem direta ou indiretamente o meio ambiente, também irão prejudicar todos os seres.

Segundo Mateo "o homem de hoje usa e abusa da natureza como se fosse o último inquilino deste infeliz planeta, como se um futuro não fosse anunciado por trás dele. A natureza torna-se assim o bode expiatório do progresso"19.

Notadamente, a sociedade contemporânea produz riscos que podem ser controlados e outros que escapam ou neutralizam os mecanismos de controle típicos da sociedade industrial. A sociedade de risco revela-se, portanto, como um modelo teórico que marca a falência da modernidade, emergindo um período pós-moderno, na medida em que as ameaças produzidas ao longo da sociedade industrial começam a tomar forma.

Os pilares da concepção moderna de civilização já não conseguem mais explicar os desenvolvimentos da ciência e da sociedade. A verdade científica considerada pronta, determinada e imutável, foi tomada, por bastante tempo, como paradigma para justificar a intervenção humana no meio ambiente. A natureza foi entendida como um sistema dissociado da sociedade, ao qual se podia recorrer ilimitadamente, tendo um viés meramente utilitário, ou seja, para satisfazer apenas as necessidades do homem.

Contudo, o direito esta tentando dar conta de tal complexidade, implantando novas normas, do âmbito internacional ao municipal, para servir de instrumento de proteção do meio ambiente e da sociedade como um todo. Com este escopo, houve a intervenção do direito em matéria ambiental, através da proteção de direitos difusos, dando suporte à manutenção do ambiente ecologicamente equilibrado, o qual é bem de uso comum do povo, e essencial à sadia qualidade de vida, assegurado na Constituição da República Federativa do Brasil.

Entretanto, a fragmentação que depende diretamente da força que os setores sociais independentes da economia e da política serão capazes de exercer na atualidade e nos anos subsequentes. A autonomia privada depende diretamente de um sistema social que revela-se na

\footnotetext{
18 TEUBNER, Gunther. Global Bukowina: Legal Pluralism in the World Society. In: Gunther Teubner (ed.) Global law without state. Great Britain: Datmouth Publishing Company Limited, 2003, p. 22.

19 "el hombre de hoy usa y abusa de la naturaleza como si hubiera de ser el último inquilino de este desgraciado planeta, como si detrás de él no se anunciara un futuro. La naturaleza se convierte así en el chivo expiatorio del progresso". MATEO, R. M. Tratado de derecho ambiental. Madrid: Trivium, v.1, 1991. p.27.
} 
existência de um maquinário de produção normativa (mecanismos de consenso, organizações formais, padronização) desempenhando um papel de fonte independente do direito ${ }^{20}$.

Basta analisar como exemplo a existência de uma Sociedade Contemporânea em nível globalizado, onde dimensões comunicacionais são mundializadas, que emerge a partir do momento histórico em que a comunicação torna-se universal. Segundo G. Teubner, ocorre a autonomização de processos comunicacionais em dimensão global, com a fragmentação da sociedade em dimensões comunicativas altamente dinâmicas, complexas e que, como condição de sua operacionalidade, envolvem conhecimentos e tecnologias altamente desenvolvidas e específicas. A partir dessa perspectiva, observa-se que a autonomização dos sistemas sociais acarreta na formação de espaços de decisão que atuam e operam em nível global ${ }^{21}$.

Nesse viés, o Direito Ambiental objetivou um desenvolvimento de forma sustentável, o equilíbrio entre a ação humana e a capacidade de suporte do Planeta Terra, preservando a natureza e o meio em que se vive para as presentes e futuras gerações. Há que se repensar e se aplicar imediatamente um modelo de desenvolvimento que leve em consideração as gerações futuras e uma política que tenha como base a preservação dos recursos naturais a longo prazo ${ }^{22}$.

Por outro lado, na sociedade pós-moderna, o risco é existente, todavia, é algo inerente à própria origem das civilizações, como se extrai do entendimento de Bello Filho:

[...] As incertezas mencionadas por teorias do risco que caracterizam a sociedade pós-moderna como uma 'sociedade do risco' são apenas sensações dos tempos atuais. Em épocas onde a própria complexidade da sociedade era diminuta e onde o pouco domínio do Homem sobre a natureza justifica inseguranças e incertezas as possibilidades de risco eram muito mais relevantes do que as atuais $[\ldots]^{23}$.

Percebe-se que a característica fundamental da pós-modernidade é a sociedade de risco. Neste mesmo sentido, Bauman relata que há atualmente o "caráter líquido dos conceitos clássicos"24. Tudo que é sólido desvanece no ar. Ressalta que a insegurança e incerteza faz parte de toda área de conhecimento, inclusive no Estado de Direito Ambiental.

20 TEUBNER, Günther. Após a privatização: conflitos de discursos no direito privado constante da obra Direito, Sistema e Policontexturalidade. Piracicaba: Unimep, 2005.

21 TEUBNER, Gunther. Global Bukowina: Legal Pluralism in the World Society. In: Gunther Teubner (ed.) Global law without state. Great Britain: Datmouth Publishing Company Limited, 2003, p. 23.

22 LEITE, J. R. M.; AYALA, P. A. Dano ambiental: do individual ao coletivo extrapatrimonial - teoria e prática. 3. ed. São Paulo: RT, 2010. p. 27.

${ }^{23}$ LEITE, José Rubens Morato; FILHO, Ney Barros Bello. Direito Ambiental Contemporâneo. São Paulo: Manole. 2004. p. 162.

${ }^{24}$ BAUMAN, Zygmunt. Modernidade líquida. Rio de Janeiro: Jorge Zahar, 2001. p.20. 
Contudo o direito privado deve funcionar de modo a quebrar o acoplamento de cada setor com a economia e fortalecer os aspectos ambientais relacionados. Satisfazendo a normatividade interna do sistema social. Com isso, há alteração dos processos de criação normativa do direito privado (irritação por acontecimentos externos). As irritações não serão exclusivamente captadas no mercado, mas pelas necessidades da reconstrução jurídica quando do restabelecimento do padrão social. Assim o papel do direito privado seria defender as esferas de autonomia social da influência totalizante da economia ${ }^{25}$, tendo-se em vista os desastres ambientais a nível global.

Sabe-se que um fator ambiental afetado raramente é possível proceder à reconstituição da situação anterior à verificação do dano. Pois o dano ambiental é específico e exige a adoção de políticas preventivas, as únicas que, com total eficácia, conseguem o equilíbrio ambiental desejado. Contudo, ora pela inoperância das políticas preventivas, ora pela impossibilidade da sua aplicação, existem e, infelizmente, cada vez mais, danos ambientais ${ }^{26}$.

Superado o conceito de direito rigoroso de Hans Kelsen ${ }^{27}$, a sociedade contemporânea “contempla a criação de um direito mais 'flexível', diante da possibilidade de articulação de

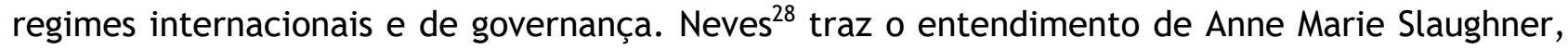
as redes governamentais em uma ordem mundial desagregada, nas quais fariam parte redes horizontais e redes verticais, bem como, redes que coletassem e partilhassem informações variadas, para a existência de uma coordenação política, cooperação, assistência e treinamento técnico e até, talvez, para a produção de normas. Segundo, Slaughner, elas seriam bilaterais, plurilaterais, regionais ou globais. Tomadas em conjunto, forneceriam o esqueleto ou a infraestrutura da governança global. Desta forma, com constitucionalismo e com o panorama da globalização, foi possível identificar a formação de ordens jurídicas globais que não centravam sua regulação na figura estatal, porém conferindo legitimidade a essas ordens.

Gunther Teubner, idealizador do constitucionalismo societário sem Estado, traz à baila o direito na era da globalização e as relações de conflito e a concorrência existente entre as normas legisladas e aquelas criadas à margem do Estado, a qual traz um enfraquecimento das Constituições diante do soft law criado por entes transnacionais, encontrado, pois, a

\footnotetext{
25 TEUBNER, Günther. Após a privatização: conflitos de discursos no direito privado constante da obra Direito, Sistema e Policontexturalidade. Piracicaba: Unimep, 2005.

${ }^{26}$ FERREIRA, H. S.; LEITE J. R. M. Estado de direito ambiental: tendências, aspectos constitucionais e diagnósticos. Rio de Janeiro: Forense Universitária, 2004. p. 129.

27 KELSEN, Hans. Teoria Pura do Direito. 7. Ed. São Paulo: Martins Fontes, 2006.

${ }^{28}$ NEVES, Marcelo. Transconstitucionalismo. São Paulo: Martins Fontes, 2009.
} 
necessidade de deixar de lado as “ordens jurídicas hierárquicas tradicionais" e substituí-las por ordens hierárquicas compatíveis com as redes globais ${ }^{29}$.

Observa-se, também a importância de tratar de um fenômeno atual e que tem crescido progressivamente, que é a realidade de Direito Internacional Privado para que decisões constitucionais atualmente tenham validade interna. Neste sentido, Neves expõem que: "sem desconhecer da emergência de novos atores, sistemas, regimes ou redes globais com pretensão de tomar decisões coletivamente vinculantes e produzir normas jurídicas, leve em conta que o Estado ainda é o foco fundamental da reprodução da nova ordem normativa mundial”30

Segundo Neves, evidencia-se também a existência de organizações que atuam em escala global, bem como de problemas comuns entre as diversas ordens jurídicas, a exemplo de danos ambientais, tendo em vista que a poluição e os danos não conhecem fronteiras. Para tal, pressupõe que o diálogo constitucional (transconstitucionalismo) é capaz de reativar o papel de centralidade dos sistemas do Direito e da política em um contexto de sociedade mundial ${ }^{31}$. Portanto, o diálogo constitucional, o que denomina transconstitucionalismo, parte da perspectiva sociológico-sistêmica da existência de uma sociedade mundial e, consequentemente, de sistemas do Direito e da política em escala global ${ }^{32}$.

\section{A PROTEÇÃO PENAL AMBIENTAL E A COOPERAÇÃO ENTRE OS ESTADOS}

Devido à problemática contemporânea, isto no que consiste a crise ambiental a delimitação histórica do risco, o que se vê de forma clara é que, cada vez mais, o risco ocupa um espaço relevante nos modelos sociais, econômicos, políticos e jurídicos adotados, o que acarreta na transdisciplinaridade de temas que o envolvem, como a questão ambiental ${ }^{33}$, possibilitando que os problemas com grande repercussão jurídica a nível global, tal qual é a proteção ao Direito Ambiental, o implemento do desenvolvimento sustentável e o alcance de resultados diretos em nível de experiência internacional, de forma a trazer celeridade para sua aplicabilidade e conhecimento interno.

29 TEUBNER, Gunther. Fragmentos constitucionais: constitucionalismo social na globalização. São Paulo: Saraiva, 2016. p. 195.

30 NEVES, Marcelo. Transconstitucionalismo. São Paulo: Martins Fontes, 2009. p. 34.

31 NEVES, Marcelo. Transconstitucionalismo. São Paulo: Martins Fontes, 2009.

32 NEVES, Marcelo. Transconstitucionalismo. São Paulo: Martins Fontes, 2009.

33 BAUMAN, Zygmunt. Modernidade líquida. Rio de Janeiro: Jorge Zahar, 2001. p.20-30. 
Neste prisma, analisa-se o "Estado ambiental" e o que significa o dever de reduzir os riscos à qualidade dos recursos naturais, antes de se adentrar na análise do dever de informar de que trata o artigo 78 da Lei dos Crimes Ambientais, no plano do Direito brasileiro.

Inicialmente, cabe destacar que a influência de uma ordem pública global sobre o sentido das ações políticas no Direito brasileiro pode ser visualizada já a partir de sua arquitetura constitucional, que encontra seu fundamento em um dever geral de solidariedade para com a humanidade, mensagem emancipatória que foi considerada no âmbito de um projeto político de sociedade que prioriza e enfatiza o bem-estar coletivo como tarefa determinante da qual depende a manutenção da ordem pública e social.

Sob esse contexto, ganha ênfase a posição angular que recebe o "princípio da dignidade da pessoa humana" em semelhante regime de governança, que projeta suas consequências em realidades sociais e ecológicas da existência da pessoa nesse espaço público ${ }^{34}$.

Baseado nesse primado da dignidade (art. $1^{\circ}$, III, da CF/1988) e em um dever geral de solidariedade para com a humanidade (arts. 3, I, e 225, caput, da CF/1988), modificações substanciais podem ser constatadas no projeto de ordem social proposto pela atual Constituição brasileira, o qual também se projeta como uma tendência em visível expansão em outras experiências ocidentais ${ }^{35}$.

A afirmação política e normativa de um objetivo de solidariedade e de compromisso para com as gerações presentes e futuras, como os que se encontram expressos nos artigos $3^{\circ}$, III, e 225, caput, da CF/1988, impõem a sujeição do Estado e dos particulares ao dever de autor restrição no livre exercício da autonomia da vontade.

Nem todas as escolhas são toleráveis e admissíveis pelo projeto de sociedade (que, neste caso, também é um projeto de futuro) ${ }^{36}$ definido pela ordem constitucional brasileira. Cumpre às funções estatais obstar excessos na definição das escolhas sobre como é possível e como se desenvolverá a existência da humanidade. Isso porque o excesso no exercício de tal capacidade de escolha e a sujeição dessa sociedade a determinados modelos de desenvolvimento, incapazes de assegurar a existência de todas as formas de vida, representam comportamentos de deslealdade com semelhante proposta de cultura constitucional que orienta

\footnotetext{
${ }^{34}$ SARLET, Ingo Wolfgang. Dignidade da pessoa humana e direitos fundamentais na Constituição Federal de 1988. 3. ed. rev., atual. e ampl. Porto Alegre: Livraria do Advogado, 2004. p. 29-75.

${ }_{35}$ AYALA, Patryck de Araujo. Riscos biotecnológicos e o princípio constitucional da imparcialidade no direito ambiental brasileiro. Rio de Janeiro: Lumen Juris, 2011. p.173-230.

36 AYALA, Patryck de Araújo. A prova científica e o dever de imparcialidade na tutela coletiva ambiental. In: MILARÉ, Edis (coord). Ação civil pública após 25 anos. São Paulo: Revista dos Tribunais. 2010, p. 640.
} 
o modelo contemporâneo de um Estado comprometido com tarefas sociais, econômicas, culturais e ecológicas.

Contudo, o princípio da precaução, um dos pilares do Direito Ambiental, esvai-se por toda a ordem jurídica, não apenas no direito material, mas também em disciplinas instrumentais. No âmbito de uma sociedade de risco, Beck aponta o conceito de irresponsabilidade organizada, pois, apesar da consciência da existência dos riscos, esses são ocultados pelo Poder Público e ainda pelo setor privado ${ }^{37}$.

Assim, a irresponsabilidade organizada acaba transformando o Estado em faz-de-conta, em Estado fantoche, que só dá publicidade aos fatos científicos de acordo com seus interesses. Como o desenvolvimento econômico ainda é o foco das políticas públicas, ou seja, o discurso padrão das autoridades há uma invisibilidade dos riscos ecológicos. Referida invisibilidade decorre do fato de que o Estado utiliza-se de meios e instrumentos para ocultar as origens e os efeitos do risco ecológico, com o intuito de minimizar suas consequências, ou melhor, objetivando transmitir para a sociedade que a crise ambiental encontra-se controlada.

Assim, a sociedade atual está pautada em uma irresponsabilidade organizada, haja vista que as instituições públicas e civis parecem ainda não terem despertado para a necessidade de uma gestão compartilhada do risco. Nesse sentido, o Direito, como ciência, precisa abrir espaços para discussões em torno de novas formas de sociabilidade, por meio da criação de instrumentos jurídicos que busquem trazer à baila formas de gerenciamento preventivo do risco, como por exemplo: o licenciamento ambiental, baseadas nos princípios da prevenção, da precaução e da responsabilização.

Amplia-se a preocupação com as gerações futuras devido aos reflexos do Direito Ambiental. Com tudo apesar da íntima ligação entre os termos, desenvolvimento sustentável não se confunde com sustentabilidade. Aquele é o meio para se alcançar o último. Ou seja, é preciso desvendar o caminho de uma forma de desenvolvimento ecologicamente correta para então se buscar a sustentabilidade nas suas mais variadas formas. Em linhas gerais, o principio do desenvolvimento sustentável visa à manutenção das bases vitais da produção e reprodução ao garantir uma relação satisfatória entre o homem e o meio ambiente. Assim, as futuras gerações podem ter o direito de desfrutar dos recursos que hoje estão à disposição.

37 BECK, Ulrich. A reinvenção da política: rumo a uma teoria da modernização reflexiva. In: BECK, Ulrich; GIDDENS, Anthony; LASH, Scott. Modernização reflexiva: política, tradição e estética na ordem social moderna. São Paulo: UNESP, 1997. 
Em um modelo de Estado exposto a exigentes desafios e tarefas capazes de interferir em realidades existenciais de longo curso, a dignidade da pessoa humana passa a constituir-se em postulado primário para a compreensão do alcance que tais objetivos de proteção (antes associados a uma dimensão antropocêntrica de uma existência efêmera) passaram a assumir nas sociedades presentes no mundo contemporâneo.

A tarefa estatal de assegurar o bem-estar ganha, portanto, a partir da afirmação de um Estado ambiental, dimensões bem mais extensas em relação ao alcance de semelhante dever. Este the impõe severas exigências de escala para a consecução da tarefa de assegurar o bemestar social, pois os valores da sociedade que se quer proteger estão vinculados agora aos interesses de titulares e beneficiários que ainda não participam da comunidade política, a saber, os animais não humanos e, principalmente, as gerações vindouras ${ }^{38}$.

Isso somente se faz possível a partir de um modelo de cultura constitucional fundado em um pluralismo moral (responsável pelo alargamento da comunidade moral que justifica os interesses protegidos $)^{39}$, pressuposto indispensável para que o sentido do primado da dignidade da pessoa humana possa proporcionar uma proteção reforçada para todos aqueles que têm algum interesse afetado e possam de algum modo, compreender e vivenciar o valor dignidade.

Decorre do direito (humano e fundamental) ao meio ambiente um conjunto de deveres estatais e sociais de garantia da qualidade de vida, sob uma perspectiva pela qual esta é o efeito da combinação de um complexo de variáveis (econômicas, sociais, culturais, ambientais, etc.). Tem-se, aqui, um direito econômico, social e cultural, também garantido pelo Direito Internacional por meio de convenções específicas, cujo exemplo mais concreto é o Pacto Internacional dos Direitos Econômicos, Sociais e Culturais (celebrado em Nova York, em 1966, sob os auspícios das Nações Unidas) ${ }^{40}$. De sua realidade objetiva pode-se reconhecer um conjunto de deveres, todos vinculados a uma meta de aperfeiçoamento da proteção, que

\footnotetext{
38 Saliente-se que a tarefa referida já se encontrava desvinculada de uma perspectiva utilitária de otimização das pretensões e expectativas individuais, uma vez que já não é recente na dogmática pública a afirmação de um sentido social, cuja expressão se refletia em objetivos de segurança social à coletividade, próprios de um Estado social de direito. Este, por sua vez, representa uma perspectiva de proteção que é adicionada (não exprimindo, portanto, uma noção de superposição ou de substituição de projetos políticos por projetos autônomos) àquela primeira, própria de uma orientação liberal para o exercício do poder político, cuja expressão também se refletia na definição do conteúdo dos direitos humanos e fundamentais. Essa definição priorizava a garantia do livre desenvolvimento da personalidade, para a qual era fundamental o livre exercício das liberdades econômicas e civis.

${ }^{39}$ AYALA, Patryck de Araújo. A prova científica e o dever de imparcialidade na tutela coletiva ambiental. In: MILARÉ, Edis (coord). Ação civil pública após 25 anos. São Paulo: Revista dos Tribunais. 2010.

${ }^{40} \mathrm{Em}$ vigor no Brasil desde 24.04.1992, na forma de seu art. 27, § $2^{\circ}$ (cf. Dec. 591, de 06.07.1992).
} 
somente pode ser atingida mediante a redução dos níveis de risco a que a coletividade se encontra exposta diariamente ${ }^{41}$.

Não se trata de um dever exclusivamente estatal, senão de um dever social. Todos devem ser capazes de mitigar os efeitos externos de suas escolhas, e há de ser o exercício das liberdades econômicas condicionado pela necessidade de assegurar que o desenvolvimento da vida se estenda de forma duradoura.

O dever (estatal e social) de reduzir os riscos envolve escolhas em longo prazo e compromissos permanentes para com o desenvolvimento da vida e de todas as formas de vida, sendo este o objetivo de maior proeminência de um Estado ambiental.

Elevar os níveis de qualidade de vida requer um forte compromisso com a redução dos riscos existenciais. Nesse sentido, um Estado que adote legislação interna conforme as normas internacionais de proteção (tanto na seara dos direitos humanos lato sensu, como do direito ambiental stricto sensu) é um Estado mais apto a reduzir os riscos existenciais, elevando consequentemente os níveis de qualidade de vida.

Esses dois objetivos do Estado ambiental de reduzir os riscos existenciais e elevar os níveis de qualidade de vida, não fazem com que o Estado deixe de ser um Estado social, mas comungam esforços para que seja um Estado no qual o objeto da proteção social é alargado para alcançar elementos ecológicos, como parte integrante desse projeto existencial de qualidade de vida.

E nesse contexto, social, político e, agora, jurídico, que o tema da cooperação internacional para a proteção do meio ambiente há de ser examinado. Tem-se, aqui, um paradoxo vinculado ao contexto de riscos contemporâneos, que se encontra posicionado como veículo de conflitos, ao menos na experiência jurídica brasileira.

Em um Estado ambiental exposto a ameaças e aos efeitos de problemas ambientais de segunda geração, ou seja, efeitos combinados dos vários fatores de poluição e das suas implicações globais e duradouras como o efeito estufa, a destruição da camada de ozônio, as mudanças climáticas e a destruição da biodiversidade ${ }^{42}$, somente se pode conceber uma proteção reforçada para os interesses de uma comunidade moral heterogênea e complexa a

\footnotetext{
${ }^{41}$ SANDS, Philippe. Human rights and the environment: proceedings of a Geneva Environment Network roundtable. Geneva: United Nations Environment Programme for the Geneva Environment Network, 2004. p.22-28.

42 CANOTILHO, José Joaquim Gomes. Direito constitucional ambiental português: tentativa de compreensão de 30 anos das gerações ambientais no direito constitucional português. In: Canotilho, José Joaquim Gomes; Leite, José Rubens Morato. (Orgs.) Direito constitucional ambiental brasileiro. 3. ed. São Paulo: Saraiva, 2009.
} 
partir de um reforço sobre a própria consideração do primado da dignidade da pessoa humana, situado que está agora em uma cultura constitucional moralmente plural ${ }^{43}$.

Só se pode conceber dignidade a partir de uma referência deôntica que considera a coletividade sob uma perspectiva de escala diferenciada, vinculada à noção de humanidade. Portanto, o dever estatal e os deveres fundamentais atribuídos a cada membro dessa comunidade política não se esgotam (no projeto de sociedade delineado pela Constituição brasileira) na garantia do bem-estar e na qualidade de vida desses mesmos membros, senão apontam para uma tarefa (estatal) e para deveres (estatais e sociais) perante toda a humanidade. 0 princípio da dignidade da pessoa humana impõe, nessa direção, deveres estatais e deveres fundamentais sujeitos a uma escala exigente de concretização.

A dignidade humana, situada como primado que condiciona a realização das tarefas estatais adquire um significado diferenciado quando contextualizada perante um conjunto de valores de uma sociedade plural e de uma comunidade moral axiologicamente complexa, contribuindo, para a afirmação da inclusão dos animais não humanos e da natureza na esfera protetiva, conjuntura que só se faz possível porque a definição dos valores que devem ser protegidos vincula-se e está fundamentada em uma ordem permanentemente aberta. Esta, por sua vez, tem na configuração contemporânea de Estado sua manifestação jurídico-política ${ }^{44}$.

Considerando-se o conjunto dos argumentos analisados, e se é correto admitir que a sobrevivência e o livre desenvolvimento da personalidade das pessoas dependem de que sejam garantidos ou mantidos determinados níveis de qualidade aos recursos naturais em geral, é possível atribuir à natureza a condição de bem, que manifesta um valor independente de suas utilidades econômicas ou da satisfação de necessidades humanas imediatas, razão pela qual as ordens constitucionais atuais, situadas que estão no contexto de projetos emancipatórios de qualidade diferenciada, tendem a reconhecer e a exprimir o valor de existência da natureza (e o valor de existência de outras formas de vida) como manifestação de um pluralismo moral na definição das tarefas estatais de proteção.

Boa parte da doutrina entende que o desenvolvimento sustentável é um princípio da ordem econômica, nos termos do art. 170, IV, Constituição. No entanto, apesar de assumir o patamar de princípio constitucional, nada obsta que exista um valor sustentabilidade, 0 Estado

43 CANOTILHO, José Joaquim Gomes. Direito constitucional ambiental português: tentativa de compreensão de 30 anos das gerações ambientais no direito constitucional português. In: Canotilho, José Joaquim Gomes; Leite, José Rubens Morato. (Orgs.) Direito constitucional ambiental brasileiro. 3. ed. São Paulo: Saraiva, 2009. p. 22.

${ }^{44}$ MAZZUOLI, Valerio de Oliveira. Tratados internacionais de direitos humanos e direito interno. São Paulo: Saraiva, 2010. 
de Direito Ambiental e a particularidade de uma medida internacional advindas do transconstitucionalismo, objetivando o desenvolvimento econômico, equidade social e equilíbrio ambiental.

Assim, o desenvolvimento sustentável preconiza que, não só as presentes gerações, mas também as futuras, devam suprir suas necessidades em termos econômicos, sociais e ambientais. No que concerne à sustentabilidade, Winter debate a configuração de duas pirâmides para apontar a situação das futuras gerações: uma fraca e outra forte ${ }^{45}$.

A sustentabilidade fraca trata da mesma forma os elementos econômico, social e ambiental. 0 equilíbrio ambiental seria apenas um deles, estando todos interligados de forma sistemática e holística. Seria a manifestação do desenvolvimento sustentável. Já na sustentabilidade forte, o autor coloca o recurso natural como base da pirâmide e, consequentemente, dos demais elementos. Nessa linha, Winter aponta a necessidade de o sistema considerar a sustentabilidade forte, a fim de minimizar os impactos da crise ambiental. Conclui o autor falando da importância do conceito, mas alerta: "ainda permanecem muitos pontos a serem clarificados, como, em particular, o relacionamento de pesos entre a preservação da natureza e os usos humanos em diferentes escalas. No curso de tais concretizações, o processo de construção do direito pode avançar"46.

É importante notar neste debate da sustentabilidade “fraca" e a "forte". A primeira toma como condição necessária e suficiente a regrinha de que cada geração, à segunda é a somatória de três tipos de capital que considera Intersubstituíveis: o natural/ecológico, e o humano/social. Na contramão está a sustentabilidade "forte", que destaca a obrigatoriedade de que pelo menos os serviços do "capital natural” sejam mantidos constantes.

Percebe-se que o cidadão é o fio condutor desta sustentabilidade e deve usar de sua razão para manter os elementos necessários à qualidade ambiental e ao sistema ecológico, afastando-se do mito do desenvolvimento sustentável em um tripé em que a parte econômica sempre funciona como base fundamental. A crise ambiental e a sociedade de risco, portanto, demandam transformação no Estado e no Direito, que têm como objetivo principal manter a ordem social. É necessário um novo papel do Estado, na medida em que a intervenção estatal baseada na regulação sancionatória que emana do princípio da solidariedade, que acaba se esvaindo por toda a ordem jurídica.

\footnotetext{
45 WINTER, Gerd. Desenvolvimento sustentável, OGM e responsabilidade civil na União Europeia. Campinas, São Paulo: Milennium, 2009.

46 WINTER, Gerd. Desenvolvimento sustentável, OGM e responsabilidade civil na União Europeia. Campinas, São Paulo: Milennium, 2009. p. 22.
} 
Dessa forma, existe o princípio do desenvolvimento sustentável e o valor da sustentabilidade clássica não vem sendo suficiente como mecanismo de proteção ao meio ambiente. Em relação ao Direito, destaca-se que este não exerce tão somente a função tradicionalmente repressiva, mas também, como já defendido por Bobbio, uma função promocional, em que o Estado assume o papel de encorajador (e premiador) ou desencorajador de condutas ${ }^{47}$.

A própria definição do conteúdo das tarefas públicas é visivelmente influenciada pela modificação das relações de poder que se desenvolvem em escala global, bem como pelos objetivos e pelos consensos obtidos em um espaço multilateral de negociações. Perante a constatação de ameaças que podem comprometer a existência da humanidade, faz-se necessário que os Estados se responsabilizem com semelhante tarefa também no plano nacional, e por meio do exercício das funções legislativa, executiva e judiciária, para que possa ser atingido o objetivo de redução dos riscos.

Esse resultado decorre, inclusive por meio de legislação e de procedimentos que asseguram a redução das emissões, e de suas fontes, ocorre no plano nacional, mas suas consequências se projetam em escalas espaciais diferenciadas, em maior ou menor grau.

Assim, o Estado e o Direito precisam assumir um papel de estimular condutas ambientalmente desejáveis, ou desestimular outras, na missão de combater a crise ambiental e lutar pela sobrevivência da humanidade ${ }^{48}$.

Nesse sentido, urge a construção de um Estado de Direito Ambiental que venha a se adequar à crise ecológica e à sociedade de risco, possuindo princípios fundantes e estruturantes, contornos e metas para tentar minimizar os efeitos dos impactos negativos no meio ambiente. Para demonstrar essa nova organização, segundo Paulo de Castro Rangel, surge a partir do:

“Estado de Direito Ambiental sob um critério estrutural-funcional, no qual,
quanto à estrutura do Estado nas relações entre este e Sociedade, surge um
Estado que ultrapassa o modelo intervencionista de inspiração keynesiana,
promovendo uma postura de transação-negociação direta com os singulares
cidadãos e demais pessoas jurídicas. Há um estímulo à participação cidadã
através de órgãos com ou sem capacidade organizativa e reivindicativa. Para o
mesmo autor, já no que diz respeito ao ponto de vista funcional, o Estado assume
novas tarefas, tais como a defesa do meio ambiente e promoção da qualidade de
vida que, consistem em fins qualitativa e substancialmente diversos dos

47 BOBBIO, Norberto. Da estrutura à função: novos estudos de teoria do direito. Tradução de Daniela Beccacia Versiani. São Paulo: Manole, 2007. p. 43-45.

${ }^{48}$ MATIAS, João Luis Nogueira; BELCHIOR, Germana Parente Neiva. Direito, economia e meio ambiente: a função promocional da ordem jurídica e o incentivo a condutas ambientalmente desejadas. In: Revista NOMOS. Fortaleza, v. 27, p. 155-176, jul./dez., 2007. p. 160. 
anteriores (Estado de Direito e Estado Social), muitas das vezes inclusive conflitantes com estes" ${ }^{49}$.

Nota-se, que essa é a tendência de inserção da proteção ambiental como objetivo fundamental do Estado. Isso permite o surgimento da "hipótese do Estado de Direito Ambiental”, cuja finalidade consiste na defesa do ambiente e promoção da qualidade de vida ${ }^{50}$.

Por outro lado, de nada adianta uma ordem jurídica ambiental avançada no que concerne ao gerenciamento preventivo e compartilhado do risco, se o Estado parece não reunir esforços para tornar a legislação efetiva e operacional. Notadamente, a necessidade da construção de um Estado de Direito Ambiental implica em mudanças profundas na estrutura da sociedade e na atividade estatal, com o objetivo de apontar caminhos em resposta aos novos pilares de uma sociedade de risco.

Esse cenário também expõe uma nova realidade para a arquitetura das relações de poder a partir de padrões de governança tipicamente associados à forma de se atingir objetivos globais que não podem ser alcançados exclusivamente por uma atuação apenas nacional, ou ainda, pela iniciativa de organismos internacionais ${ }^{51}$.

Pois o Estado deixou de ser o lócus (lugar) privilegiado de solução de problemas constitucionais. Embora fundamental e indispensável, é apenas um dos diversos loci (locais) em que ocorre a cooperação e concorrência na busca do tratamento desses problemas ${ }^{52}$. Tendo em vista que a sociedade de risco aponta como característica fundamental da pós-modernidade, a liquidez e a insegurança e incerteza estão se espalhando por todos os ramos de conhecimento, inclusive o Direito ${ }^{53}$. Desta forma, a integração sistêmica cada vez maior da sociedade mundial levou à desterritorialização de problemas-caso jurídico-constitucionais, que, por assim dizer, emanciparam-se do Estado ${ }^{54}$. 0 objetivo de assegurar processos eficazes para a adaptação perante os efeitos das mudanças climáticas globais expõem uma preocupação que se vincula ao interesse de toda a humanidade, diante da ameaça real de degradação de sua existência.

\footnotetext{
49 RANGEL, Castro Rangel. Concertação, programação e direito do ambiente. Coimbra: Coimbra Editora, 1994, p. 19-20.

${ }^{50}$ RANGEL, Castro Rangel. Concertação, programação e direito do ambiente. Coimbra: Coimbra Editora, 1994, p. 33.

51 ANDRESEN, Steinar. Global environmental governance: UN fragmentation and co-ordination. In: Stokke, Olav Schramm; Thommessen, Oystein B. (Eds.) Yearbook of International Co-operation on Environment and Development 2001/2002. London: Earthscan Publications, 2001. p.19-26.

52 NEVES, M. Transconstitucionalismo. São Paulo: WMF Martins Fontes, 2009. p. 295.

${ }^{53}$ BAUMAN, Zygmunt. Modernidade líquida. Rio de Janeiro: Jorge Zahar, 2001. p. 20-30.

${ }^{54}$ NEVES, M. Transconstitucionalismo. São Paulo: WMF Martins Fontes, 2009. p. 297.
} 
Entretanto, tais objetivos só podem ser atingidos pela conjugação de estruturas institucionais capazes de se comunicar e interagir entre si, o que só se afigura possível quando existe cooperação entre os Estados, de maneira integrada, com o transconstitucionalismo, que permite às múltiplas ordens jurídicas, em vista dos seus ideários variados, realizar um acoplamento de estruturas, Nestes prismas, o aproveitamento dos fundamentos jurídicos normativos e das decisões das cortes de ordens jurídicas externas permite um aprendizado mais rápido com a experiência no exterior, possibilitando que os problemas com grande repercussão jurídica a nível global, tal qual é a proteção ao Direito Ambiental e o implemento do desenvolvimento sustentável. Assim, é passível que se alcancem resultados diretos em nível de experiência internacional, de forma a trazer celeridade para sua aplicabilidade e conhecimento interno.

\section{A IMPLANTAÇÃO DA PROTEÇÃO AMBIENTAL POR MEIO DO TRANSCONSTITUCIONALISMO}

O Direito Ambiental dispõe de uma legislação, programas e ações de excelência, contudo sua aplicabilidade ainda é utópica no Brasil. E a proteção ao meio ambiente vem ocupando lugar de destaque, devido as consequências de uma degradação ambiental local que chegarão a repercutir sobre todo o globo terrestre, vindo a ocasionar danos ambientais para uma pluralidade de ordens jurídicas, repercutindo como um problema de caráter constitucional e com conjectura internacional.

Neste sentido, objetiva-se a efetiva proteção do meio ambiente ecologicamente equilibrado, mas para tanto há uma necessidade emergencial de se pensar como acontecerá essa mudança de forma global, umas das alternativas que se tem ganhado alcance na conjuntura internacional, o qual é denominado transconstitucionalismo que é um instrumento que, em casos tipicamente constitucionais, as decisões de cortes constitucionais de outros Estados, a partir de tribunais, envolvendo comunicação entre decisões de diferentes Cortes abrangendo os problemas comuns na sociedade mundial por meio de qualquer um dos subsistemas divididos territorialmente, é possível, para Neves, promover o diálogo com os demais subsistemas, representados por tribunais ou Estados, enquanto organizações dos referidos subsistemas, para a resolução do problema comum ${ }^{55}$.

\footnotetext{
${ }^{55}$ NEVES, M. Transconstitucionalismo. São Paulo: WMF Martins Fontes, 2009. p. 297.
} 
O transconstitucionalismo implica no reconhecimento dos limites de observação de uma determinada ordem, que admite a alternativa, ou seja, "o ponto cego, o outro pode ver"56 57. Para tanto, o transconstitucionalismo faz parte vinculante da decisão como a principal razão de fundamento, de maneira forte e direta, e está presente nos processos internos de autovalidação, e não como um transplante imediato do direito estrangeiro, em que se trabalha a capacidade das respectivas cortes de atuar reflexivamente, tanto no sentido da manutenção da autoconsistência constitucional, quanto na perspectiva de abertura a um aprendizado com as experiências das outras cortes ${ }^{58}$.

Entretanto, para Canotilho:

[...] 0 direito deveria, de acordo com as suas posses, assumir a responsabilidade pela defesa da vida na terra - e não apenas do homem. Para os fundamentalistas ecológicos seria olhar com desconfiança para os juristas, mesmo para os juristas com alguma consciência ecológica. Estas não conseguem abandonar, não obstante as suas juras ambientais, o mito de Adão fora do paraíso. Os perigos estariam à vista: quando os juristas se interessam pelo ambiente devemos estar sempre de vigília, pois existirá sempre o risco de, em vez de se conseguir a ecologização do direito, se terminar encapuçadamente na juridicização da ecologia. Daí as propostas e desafios das correntes ecológica-quimicamente puras [...] os desafios aí estão: para quando um sistema jurídico reconhecedor de direitos fundamentais da natureza? Enquanto não se consagrarem, em termos jurídicos, direitos dos animais e de direitos as plantas - direitos dos seres vivos ao lado dos direitos do homem, os ecologistas continuam a olhar para o direito do ambiente como a expressão mais refinada da razão cínica $[\ldots]^{59}$

Assim, embora a lei assegure a efetividade desse direito, e chama a responsabilidade não somente o Poder Público, mas de toda sociedade e de diferentes níveis de ensino para refletir sobre a defesa do meio ambiente ecologicamente equilibrado percebe-se que não tem atingido seu objetivo.

Ocorre que situações complexas apontam para um sistema jurídico mundial de níveis múltiplos, no qual se dá um transconstitucionalismo pluridimensional, que resulta da relevância simultânea de um mesmo problema jurídico-constitucional para uma diversidade de ordens jurídicas, como é o caso do meio ambiente. No sistema mundial de níveis múltiplos, a solução dos problemas jurídicos mais relevantes se resolve mediante entrelaçamentos

\footnotetext{
${ }^{56}$ Nota-se que todo observador tem um limite de visão no "ponto cego", aquele que não pode ver em virtude de sua posição e perspectiva de observação.

${ }^{57}$ NEVES, M. Transconstitucionalismo. São Paulo: WMF Martins Fontes, 2009. p. 298.

58 NEVES, M. Transconstitucionalismo. São Paulo: WMF Martins Fontes, 2009. p. 167-171.

${ }^{59}$ CANOTILHO, José Joaquim Gomes. Direito do Ambiente e crítica da razão cínica das normas jurídicas. In Revista de Direito do Ambiente e Ordenamento do Território. №1, setembro, Lisboa: APD, 1995. p. 97.
} 
transconstitucionais entre ordens jurídicas diversas, a fim de se chegar na resposta mais plausível, incluindo, em um sistema jurídico mundial de níveis múltiplos, a ordem internacional e a ordem de outros Estados: nesse sentido, aliam-se as possibilidades de conversação transnacional entre ordens públicas ${ }^{60}$.

Contudo, o sistema do direito enfrenta um grau de possibilidades muito maior do que aquelas efetivamente realizadas. Esse excesso de possibilidade é referido pela teoria dos sistemas como complexidade. A fim de lidar com sua alta complexidade interna, a sociedade cria estruturas e as ordena de acordo com determinados princípios. Esses princípios podem ser referidos como regras de diferenciações primárias da sociedade. As regras de diferenciação primárias da sociedade são as estruturas mais gerais do sistema, que determinam a forma como se criarão as demais estruturas sociais.

No momento em que o Estado, enquanto programador do Direito deixa de ser o centro de organização da política e deixa de ser o fundamento único de validade da lei, o Judiciário, em vez de simplesmente aplicar a norma jurídica, ou seja, a programação condicional que caracteriza um sistema fechado. A legislação necessita recorrer às fundamentações extras estatais e tomando decisões de outro tipo, que é através da programação finalística que caracteriza um sistema aberto $^{61}$. Neste sentido, no momento que a normativamente do Direito de ambiental passa a ter que cumprir com sua função social, ela passa a ser um princípio organizador da sociedade, produzindo outra comunicação, outro sentido, que pode acoplar três sistemas (Jurídico, Político e Econômico). Entre estes cabe ao sistema Jurídico, por meio de decisões, regular os conflitos e, através destes, formar decisões, auto referenciais que reafirmem o sistema, todavia estas auto referências, muitas vezes sobrepõe normas sobre outras, fazendo com que algumas expectativas normativas restem frustradas, não se aplicando em certos casos. A complexidade da produção de sentido do Direito como paradoxo torna-se, assim, uma condição para a observação da comunicação do Direito, uma vez que esta constitui a capacidade da linguagem e da evolução social.

O motivo quem seja a evolução dele é a sobrevivência a complexidade, que cria constantemente novas possibilidades. Ou seja, na tentativa de reduzir a complexidade, há o incremento dela. Com o direito constitucional, isso não foi diferente, especialmente se pensarmos na diferenciação funcional do direito até chegarmos ao direito ambiental. Portanto, a diferenciação do sistema não significa decomposição de um todo em partes, mas significa dizer

60 NEVES, M. Transconstitucionalismo. São Paulo: WMF Martins Fontes, 2009. p. 235-237.

${ }^{61}$ ROCHA, Leonel Severo, Schwartz, Germano, Clam, Jean. Introdução à Teoria do Sistema Autopoiético do Direito. Porto Alegre: Livraria do Advogado, 2013. p. 44. 
que cada subsistema tem seu próprio entorno. “Não existe um agente externo que modifica, é o próprio sistema que por uma questão de sobrevivência no ambiente realiza essa diferenciação"62.

Trata-se de entrelaçamentos transconstitucionais entre ordens transnacionais e ordens estatais dificilmente se apresentam de forma isolada, ocorre, em regra, com uma pluralidade de ordens de tipos diferentes: estatais; internacionais; supranacionais e locais ${ }^{63}$.

Entretanto, isso não decorre necessariamente de um processo de internacionalização das ordens nacionais, senão de um extenso e mais profundo processo de transformação da cultura constitucional, que, por sua vez, define o projeto de sociedade que se pretende viabilizar ou que deve ser viabilizado pelas formas políticas e jurídicas ${ }^{64}$.

Situada a questão nesses termos, é possível reconhecer que ao Estado e a cada um de nós foi atribuído, pela ordem constitucional atual, um conjunto de deveres perante a humanidade. Esses deveres resultam em consequências que não conhecem limites geográficos ou fronteiras políticas, muito embora ainda decorram de decisões governamentais certamente influenciadas por fatores menos jurídicos que políticos, especialmente os de índole econômica.

É premente que se saiba que os Estados nacionais são agora formações influenciadas e integradas na estrutura de uma ordem jurídica que deixa de ser nacional, e que também não pode ser compreendida como internacional, senão como uma ordem verdadeiramente global ${ }^{65}$. Esta tem sua organização baseada em uma estrutura de redes, que não contempla a autonomia de padrões, referências morais ou culturais e procura atingir seus objetivos a partir da consideração das contradições, das divergências e das diferenças ${ }^{66}$.

Segundo THORNHILL, pesquisa sobre a constituição da sociedade global, por enquanto, há apenas limitado acordo a respeito as características exatas da Constituição global. No entanto, uma gama diversificada de perspectivas teóricas convergem em relação as transformação de direito constitucional global como um objeto de pesquisa ${ }^{67}$.

\footnotetext{
62 ROCHA, Leonel Severo; SCHERBAUM, Julia F. N. O; OLIVEIRA, Bianca N. de. Afetividade no Direito de Família. Curitiba: Juruá, 2018. p.91.

${ }^{63}$ NEVES, M. Transconstitucionalismo. São Paulo: WMF Martins Fontes, 2009. p. 235.

${ }^{64}$ HÃBERLE, Peter. Teoria de la Constitución como Ciência de la Cultura. Tradução de Emilio Mikunda. Madrid: Tecnos, 2000. p. 36-39.

${ }^{65}$ DUPUY, René-Jean. La Cloture du Système International: La Cité Terrestre. Paris: PUF, 1989. p. 115.

66 MAZZUOLI, Valério de Oliveira. Tratados internacionais de direitos humanos e direito interno. São Paulo: Saraiva, 2010. p. 130-134.

${ }^{67}$ THORNHILL, Chris. A Sociology of Transnational Constitutions: Social Foundations of the Post-National Legal Structure. Cambridge University Press. 2016.
} 
Por um lado, agora existe um vasto corpo de investigação qual alega que a constituição da sociedade global se desenvolveu através do reforço do direito internacional e é determinada, principalmente, pelo fato de que o direito internacional restringe a abstrata soberania nacional como os Estados-Membros. Nesta conta, a constitucionalidade da lei internacional é manifestar particularmente no fato de que certas leis internacionais, especialmente no que respeitam às normas de direitos humanos contidas no poderoso internacional convenções, tem poderosa força obrigatória para todos os intervenientes a domínio global. Isto é levado a dizer que, em suas atividades externas, Estados nacionais posicionarem-se como sujeitos dentro de um internacional hierarquia das normas legais e seu soberano atos estão vinculados pela jurisdição dos tribunais internacionais poderosos. Isto é levado a dizer que normas legais definidas pelas organizações e tribunais internacionais penetram profundamente nos sistemas jurídicos nacionais, para que, em suas funções internas ${ }^{68}$.

Nesse sentido, o método do transconstitucionalismo, importa na dupla contingência entre diversas ordens jurídicas, sobretudo entre os tribunais; isto na relação de observação recíproca entre os polos ego (eu, ou seja, a ordem jurídica interna) e alter (o outro, sendo as ordens jurídicas externas), na interação não só de pessoas, mas também de sistemas sociais; é um olhar pelo outro, saindo de sua zona de conforto e visualizado a problemática sobre um novo foco $0^{69}$.

O problema (da negação) do reconhecimento põe-se precisamente quando um dos polos, na relação de observação recíproca entre ego e alter, não se dispõe a suportar a liberdade do outro, tanto porque não considera o seu comportamento como ação (pois não poderia ser diverso do comportamento projetado por ego) quanto porque não leva a sério a não identidade de sua perspectiva $^{70}$.

Contudo, através da alegação generalizada de que o direito internacional dos direitos humanos é capaz, de potencialmente, assumir o direto no seio das sociedades nacionais, tendo em vista a colocação individual dos sujeitos nas sociedades nacionais em uma relação imediata com as normas legais promovido a nível supranacional. Esta construção, dos direitos humanos atuam como fontes eficazes para o direito constitucional global e cada vez mais garantem que todos os atos, tanto vertical entre pessoas e Estados nacionais e horizontal entre agentes único

68 THORNHILL, Chris. A Sociology of Transnational Constitutions: Social Foundations of the Post-National Legal Structure. Cambridge University Press. 2016.

${ }^{69}$ NEVES, M. Transconstitucionalismo. São Paulo: WMF Martins Fontes, 2009. p. 270.

70 NEVES, M. Transconstitucionalismo. São Paulo: WMF Martins Fontes, 2009. p. 270. 
na sociedade nacional, são regulados por nacionalmente e justiciáveis normas de procedência internacional ${ }^{71}$.

Por outro lado, agora também existe um corpo de literatura que examina os padrões globais de constitucionalidade de uma forma mais pluralista, sociológica perspectiva e que encara a ordem constitucional emergente da sociedade global como um formulário produzido por contingentes interações legais. Seguir esta interpretação, a sociedade contemporânea é capaz de gerar normas constitucionais altamente contingentes, e de normas constitucionais, que de fato muitas vezes resultam de processos lentos de adaptação legal ${ }^{72}$.

Nesse contexto, passa a ser dever dos Estados para com a humanidade a cooperação internacional em matéria ambiental, para a qual - nos termos do artigo 78 da Lei dos Crimes Ambientais - deve ser mantido um "sistema de comunicações apto a facilitar o intercâmbio rápido e seguro de informações com órgãos de outros países". O chamado "dever de informar", previsto no artigo 78 citado, é reflexo do impacto dos documentos internacionais no direito brasileiro, haja vista já ter sido previsto no Princípio 20 da Declaração de Estocolmo de 1972, nestes termos:

[...] Deve ser fomentada, em todos os países, especialmente naqueles em desenvolvimento, a investigação científica e medidas desenvolvimentistas, no sentido dos problemas ambientais, tanto nacionais como multinacionais. A este respeito, o livre intercâmbio de informação e de experiências científicas atualizadas deve constituir objeto de apoio e de assistência, a fim de facilitar a solução dos problemas ambientais; as tecnologias ambientais devem ser postas à disposição dos países em desenvolvimento, em condições que favoreçam sua ampla difusão, sem que constituam carga econômica excessiva para esses países $[\ldots]$.

Ao admitir a complexidade dos processos que permeiam as relações internacionais contemporâneas e que a dependência de modelos de hierarquização diminui ao mesmo tempo em que se assiste à projeção das relações de poder horizontais ${ }^{73}$, salienta que a adoção de acordos ambientais multilaterais não representa mais do que o começo, e não mais o fim, dos processos normativos internacionais.

\footnotetext{
71 THORNHILL, Chris. A Sociology of Transnational Constitutions: Social Foundations of the Post-National Legal Structure. Cambridge University Press. 2016.

72 THORNHILL, Chris. A Sociology of Transnational Constitutions: Social Foundations of the Post-National Legal Structure. Cambridge University Press. 2016.

73 BRUNNÉE, Jutta. The Stockholm declaration and the structure and processes of international environmental law. In: Chircop, Aldo; McDorman, Ted; Rolston, Susan. (Eds.). The Future of Ocean Regime Building: Essays in Tribute to Douglas M. Johnstons. Doordrecht: Martinus Nijhoff, 2008. p. 61.
} 
Uma vez que os processos pelos quais as normas de Direito Internacional do Meio Ambiente que influenciam as relações jurídicas são horizontais, substituindo padrões baseados em relações de hierarquia, é possível reconhecer que nenhum valor teria, neste momento, um dissídio que tivesse por objeto a determinação da natureza vinculante de tais normas ${ }^{74}$.

A integração sistêmica cada vez maior da sociedade mundial levou à desterritorialização de problemas-caso jurídico-constitucionais, que, por assim dizer, emanciparam-se do Estado ${ }^{75}$. É isso que ocorre com o meio ambiente e o desenvolvimento sustentável. As consequências de uma degradação ambiental local chegarão a repercutir sobre todo o globo terrestre, vindo a ocasionar danos ambientais para uma pluralidade de ordens jurídicas, repercutindo como um problema de caráter constitucional e com conjectura internacional.

Segundo Ernst-Ulrich Petersmann reconhece no constitucionalismo a eleição de valores normativos primários e hierarquizados, que constituem e limitam o poder dos governos e os direitos dos cidadãos, por exemplo: a constitucionalização da Organização Mundial do Comércio que envolve a sua submissão aos direitos humanos fundamentais e aos princípios de justiça internacional, concretizando o rule of law, reconhece expressamente a correlação entre o sistema multilateral de comércio e a realização de valores ligados aos direitos humanos, por meio do Sistema de Solução de Controvérsias ${ }^{76}$.

Assim, o Sistema de Solução de Controvérsias desempenha um papel essencial na passagem de uma inadequada perspectiva de Hobbes do Direito Internacional como instrumento de coexistência entre os Estados para à construção de um "Direito Internacional da Integração"77. Entretanto, mesmo existindo o constitucionalismo relacionado à Organização Mundial do Comércio, este se limita as concepções primitivas dos membros da Organização, que violariam a disciplina multilateral ao limitar mecanismos de transparência em aspectos democráticos e judiciais ${ }^{78}$.

74 BODANSKY, Daniel. Costumary (and not so costumary) international environmental law. Indiana: Global Legal Studies Journal, v. 3, 1995. p. 106-107.

${ }^{75}$ NEVES, M. Transconstitucionalismo. São Paulo: WMF Martins Fontes, 2009. p. 297.

76 PETERSMANN, Ernst-Ulrich. Multilevel Judicial Governance as Guardian of the Constitutional Unity of International Economic Law. Loyola of Los Angeles International and Comparative Law Review, v. 30, issue 3, p. 367- 418, 2008. p. 247.

77 PETERSMANN, Ernst-Ulrich. From the Hobbesian International Law of Coexistence to Modern Integration Law: The WTO Dispute Settlement System. Journal of International Economic Law, v. 1, issue 2, p. 175-198, 1998.

78 PETERSMANN, Ernst-Ulrich. Multilevel Judicial Governance as Guardian of the Constitutional Unity of International Economic Law. Loyola of Los Angeles International and Comparative Law Review, v. 30, issue 3, p. 233-270, 2008. p. 248. 
Assim como o atual Tribunal de Justiça da União Europeia foi essencial no desenvolvimento da ordem jurídica comunitária, transformando tratados originariamente intergovernamentais, através de interpretações constitucionais centradas no cidadão, em instrumentos constitucionais de proteção da comunidade e dos direitos individuais, percebe-se que o Sistema de Solução de Controvérsias possa de fato desempenhar papel central na proteção do meio ambiente.

Por outro lado, se os Estados possuem sua soberania condicionada por um imperativo de proteção do meio ambiente, que por sua vez se reflete por meio do dever de se prevenir danos aos recursos naturais, o reconhecimento de que as ameaças não se restringem aos efeitos de decisões nacionais implica admitir que o exercício da soberania pelos Estados depende, necessariamente, da concretização de um imperativo de cooperação, do Sistema de Solução de Controvérsias, para o fim de se assegurar, de forma duradoura, a continuidade no acesso aos recursos, ao mesmo tempo em que se viabiliza a proteção de todas as formas de vida, presentes e futuras.

Contextualizando essa análise observa-se que é fundamental, o plano de construção de uma metodologia do transconstitucionalismo, que se considere ser indispensável a reconstrução permanente da "identidade constitucional” por força de uma consideração permanente da alteridade. Isso significa a negação da identidade conforme um modelo inocente de pura convergência, e sim a prontidão para uma abertura não apenas cognitiva, mas também normativa para outra ordem entrelaçada em casos concretos ${ }^{79}$. Assim, o transconstitucionalismo se perfaz através da dupla contingência, que é a capacidade de se surpreender com os outros, na admissão de um futuro aberto, que não pode ser predefinido por nenhuma das ordens entrelaçadas no caso, procurando as descobertas normativas dos outros para fortificar a própria capacidade de oferecer solução para problemas comuns.

\section{CONCLUSÃO}

Nesse cenário, o Estado de Direito Ambiental mesmo sendo em um primeiro momento, uma teoria utópica, a supremacia das normas constitucionais, não se pode interpretar a Constituição de 1988 de maneira engessada, com a mesma lente do momento da sua

\footnotetext{
${ }^{79}$ NEVES, M. Transconstitucionalismo. São Paulo: WMF Martins Fontes, 2009. p. 272-273.
} 
promulgação, tendo em vista sua falta de eficiência para que haja a preservação de um meio ambiente sadio para os presentes e as futuras gerações.

Com base nessa perspectiva, constata-se a problemática do constitucionalismo no cenário atual acerca de sistema e organização, é preciso reler a Constituição tendo como lente a crise ambiental e a sociedade de risco, para analisar o cenário atual da teoria constitucional, ambos os autores trabalhados tanto Teubner $^{80}$, Neves $^{81}$ e Rocha ${ }^{82}$ afirmam a insuficiência da teoria tradicional do constitucionalismo para o enfrentamento dos novos problemas da ordem mundial. Trata-se, portanto, de um paradigma estatal possível de ser recepcionado pelo Estado brasileiro, evidencia-se a necessária transição para um ponto de observação da matriz analítica, de cunho normativista, para uma perspectiva a partir da matriz pragmático-sistêmica da teoria jurídica, segundo Teubner ${ }^{83}$ e Neves $^{84}$, com ênfase na organização ${ }^{85}$.

Nesse sentido Teubner ${ }^{86}$ apresenta a formação de subsistemas autopoiéticos em escala global, formando, a partir de uma racionalidade própria, o que chama de constituições. Nesse cenário, que envolve o surgimento de novos atores na sociedade mundial, passa-se de um contexto anterior de normativismo na figura do Estado Nacional para uma perspectiva de fragmentação constitucional, em que a teoria anterior, com ênfase na política e no Direito como sistemas centrais na tomada de decisões, perde seu valor tradicional.

Como resposta ao problema, propõe analisar os reflexos do transconstitucionalismo na proteção ambiental, poderia atuar sobre qualquer problemática ambiental que já tenha encontrado melhores razões jurídicas em ordem jurídica externa, não ignorando a formação de constituições autônomas com base em atores privados, mas apostando em uma possível irritação advinda de meios de comunicação de massa, a participação sendo fundamental abrir espaços decisórios autônomos como a informação, participação e interferência da coletividade nos processos de decisão ambiental a nível transconstitucional, resultando na reciprocidade de

\footnotetext{
80 TEUBNER, Gunther. Fragmentos constitucionais: constitucionalismo social na globalização. São Paulo: Saraiva, 2016. p. 170.

81 NEVES, Marcelo. Transconstitucionalismo. São Paulo: Martins Fontes, 2009.

82 ROCHA, Leonel Severo. Epistemologia jurídica: revisitando as três matrizes. Revista de Estudos Constitucionais, Hermenêutica e Teoria do Direito (RECHTD). São Leopoldo, RS, v. 5, n. 2, jul./dez. 2013. Disponível em: Acesso em: 29 mar. 2018.

83 TEUBNER, Gunther. Fragmentos constitucionais: constitucionalismo social na globalização. São Paulo: Saraiva, 2016.

${ }^{84}$ NEVES, Marcelo. Transconstitucionalismo. São Paulo: Martins Fontes, 2009.

85 ROCHA, Leonel Severo. Epistemologia jurídica: revisitando as três matrizes. Revista de Estudos Constitucionais, Hermenêutica e Teoria do Direito (RECHTD). São Leopoldo, RS, v. 5, n. 2, jul./dez. 2013. Disponível em: Acesso em: 29 mar. 2018.

${ }^{86}$ TEUBNER, Gunther. Fragmentos constitucionais: constitucionalismo social na globalização. São Paulo: Saraiva, 2016.
} 
aprendizado entre sistemas a partir de uma possível tradução de impulsos externos em incentivos internos no âmbito de cada constituição. Além da cooperação entre os estados de cunho ambiental, essencial ao aperfeiçoamento de uma cultura global de preservação ambiental. À medida que contribui para a salvaguarda do meio ambiente, faz também operar a difusão da conscientização ambiental, necessária ao esclarecimento de quais direitos se tem e que se poderá ter nesse domínio.

Portanto, ambos os principais autores apresentados mencionam novos cenários da teoria constitucional, com ênfase à atual fragmentação constitucional e à superação de um modelo tradicional de constitucionalismo com centralidade nos Estados Nacionais. Ressaltando a necessária transição entre perspectivas teóricas no atual cenário, propõem, seja a partir da elaboração de um transconstitucionalismo, alternativo como ferramenta atuante no cenário mundial, que ainda não encontrou seu devido enfoque para a esfera sustentável, mas que constata ser um importante mecanismo para atuar nas decisões nacionais internas, em um Estado ambiental global como uma forma diferenciada de realidade política e institucional visando a proteção ambiental.

\section{REFERÊNCIAS}

ANDRESEN, Steinar. Global environmental governance: UN fragmentation and co-ordination. In: Stokke, Olav Schramm; Thommessen, Oystein B. (Eds.) Yearbook of International Co-operation on Environment and Development 2001/2002. London: Earthscan Publications, 2001.

AYALA, Patryck de Araujo. Riscos biotecnológicos e o princípio constitucional da imparcialidade no direito ambiental brasileiro. Rio de Janeiro: Lumen Juris, 2011.

AYALA, Patryck de Araújo. A prova científica e o dever de imparcialidade na tutela coletiva ambiental. In: MILARÉ, Edis (coord). Ação civil pública após 25 anos. São Paulo: Revista dos Tribunais. 2010.

BAUMAN, Zygmunt. Modernidade líquida. Rio de Janeiro: Jorge Zahar, 2001.

BELL, Daniel. O Advento da Sociedade Pós-Industrial. São Paulo. Cultrix. 1974.

BECK, Ulrich. A reinvenção da política: rumo a uma teoria da modernização reflexiva. In: BECK, Ulrich; GIDDENS, Anthony; LASH, Scott. Modernização reflexiva: política, tradição e estética na ordem social moderna. São Paulo: UNESP, 1997.

BECK, Ulrich. La sociedad del riesgo: hacia una nueva modernidad. Barcelona: Paidós, 1998. 
BOBBIO, Norberto. Da estrutura à função: novos estudos de teoria do direito. Tradução de Daniela Beccacia Versiani. São Paulo: Manole, 2007.

BODANSKY, Daniel. Costumary (and not so costumary) international environmental law. Indiana: Global Legal Studies Journal, v. 3, 1995.

BRUNNÉE, Jutta. The Stockholm declaration and the structure and processes of international environmental law. In: Chircop, Aldo; McDorman, Ted; Rolston, Susan. (Eds.). The Future of Ocean Regime Building: Essays in Tribute to Douglas M. Johnstons. Doordrecht: Martinus Nijhoff, 2008.

CANOTILHO, José Joaquim Gomes. Direito constitucional ambiental português: tentativa de compreensão de 30 anos das gerações ambientais no direito constitucional português. In: Canotilho, José Joaquim Gomes; Leite, José Rubens Morato. (Orgs.) Direito constitucional ambiental brasileiro. 3. ed. São Paulo: Saraiva, 2009.

CANOTILHO, José Joaquim Gomes. Direito do Ambiente e crítica da razão cínica das normas jurídicas. In Revista de Direito do Ambiente e Ordenamento do Território. №1, setembro, Lisboa: APD, 1995.

DÍAZ REVORIO, Francisco Javier. La Constitución como Orden Abierto. Madrid:

DUPUY, René-Jean. La Cloture du Système International: La Cité Terrestre. Paris: PUF, 1989.

FERREIRA, H. S.; LEITE J. R. M. Estado de direito ambiental: tendências, aspectos constitucionais e diagnósticos. Rio de Janeiro: Forense Universitária, 2004.

HÃBERLE, Peter. Teoria de la Constitución como Ciência de la Cultura. Tradução de Emilio Mikunda. Madrid: Tecnos, 2000.

LUHMANN, Niklas. La sociedad de la sociedad. Traducción de Javier Torres Nafarrate. México: Herder, 2007.

LUHMANN, Niklas. Sistemas sociales: lineamentos para una teoria general. México: Alianza Editorial/Universidad, 1991.

LEITE, J. R. M.; AYALA, P. A. Dano ambiental: do individual ao coletivo extrapatrimonial - teoria e prática. 3. ed. São Paulo: RT, 2010.

LEITE, José Rubens Morato, FILHO, Ney Barros Bello. Direito Ambiental Contemporâneo. São Paulo: Manole. 2004.

MATEO, R. M. Tratado de derecho ambiental. Madrid: Trivium, 1991. v.1.

MILARÉ, E. Direito do ambiente: doutrina, jurisprudência e glossário. 6. ed. São Paulo: Revistas dos Tribunais, 2009.

MAZZUOLI, Valério de Oliveira. Curso de direito internacional público. 5. ed. rev., atual. e ampl. São Paulo: Ed. RT, 2011. 
MATIAS, João Luis Nogueira; BELCHIOR, Germana Parente Neiva. Direito, economia e meio ambiente: a função promocional da ordem jurídica e o incentivo a condutas ambientalmente desejadas. In: Revista NOMOS. Fortaleza, v. 27, p. 155-176, jul./dez., 2007.

MAZZUOLI, Valério de Oliveira. Tratados internacionais de direitos humanos e direito interno. São Paulo: Saraiva, 2010.

MILARÉ, Édis. Direito do ambiente. 6. ed. rev., atual. e ampl. São Paulo: Ed. RT, 2009.

NEVES, M. Transconstitucionalismo. São Paulo: WMF Martins Fontes, 2009.

PETERSMANN, Ernst-Ulrich. From the Hobbesian International Law of Coexistence to Modern Integration Law: The WTO Dispute Settlement System. Journal of International Economic Law, v. 1, issue 2, p. 175-198, 1998.

PETERSMANN, Ernst-Ulrich. Multilevel Judicial Governance as Guardian of the Constitutional Unity of International Economic Law. Loyola of Los Angeles International and Comparative Law Review, v. 30, issue 3, p. 233-270, 2008. p. 248.

RANGEL, Castro Rangel. Concertação, programação e direito do ambiente. Coimbra: Coimbra Editora, 1994, p. 19-20.

ROCHA, Leonel Severo. Direito ambiental e autopoiese. / Leonel Severo Rocha, Francisco Carlos Duarte./ Curitiba: Juruá, 2012.

ROCHA, Leonel Severo. Uma nova forma para a observação do direito globalizado: policontextualidade jurídica e estado ambiental. In: CARLIN, Volnei Ivo (Org.). Grandes temas de direito administrativo: homenagem ao Professor Paulo Henrique Blasi. Campinas: Millenium, 2009.

ROCHA, Leonel Severo; SCHERBAUM, Julia F.N.O; OLIVEIRA, Bianca N. de. Afetividade no Direito de Família. Curitiba: Juruá, 2018.

ROCHA, Leonel Severo, Schwartz, Germano, Clam, Jean. Introdução à Teoria do Sistema Autopoiético do Direito. Porto Alegre: Livraria do Advogado, 2013.

ROCHA, Leonel Severo. Epistemologia jurídica e democracia. 2. ed. São Leopoldo: Unisinos, 2005.

ROCHA, Leonel Severo. Epistemologia jurídica: revisitando as três matrizes. Revista de Estudos Constitucionais, Hermenêutica e Teoria do Direito (RECHTD). São Leopoldo, RS, v. 5, n. 2, jul./dez. 2013. Disponível em: Acesso em: 29 mar. 2018.

ROCHA, Leonel Severo. Uma nova forma para a observação do direito globalizado: policontextualidade jurídica e estado ambiental. In: CARLIN, Volnei Ivo (Org.). Grandes temas de direito administrativo: homenagem ao Professor Paulo Henrique Blasi. Campinas: Millenium, 2009. 
SANDS, Philippe. Human rights and the environment: proceedings of a Geneva Environment Network roundtable. Geneva: United Nations Environment Programme for the Geneva Environment Network, 2004.

SANDS. Principles of International Environmental Law. 2. ed. Cambridge: Cambridge University Press, 2003.

SARLET, Ingo Wolfgang. Dignidade da pessoa humana e direitos fundamentais na Constituição Federal de 1988. 3. ed. rev., atual. e ampl. Porto Alegre: Livraria do Advogado, 2004.

SOARES, G. F. S. Direito internacional do meio ambiente: emergência, obrigações e responsabilidades. São Paulo: Atlas, 2001.

TEUBNER, Günther. Após a privatização: conflitos de discursos no direito privado constante da obra Direito, Sistema e Policontexturalidade. Piracicaba: Unimep, 2005.

TEUBNER, Gunther. Direito, sistema e policontexturalidade. Piracicaba: Universidade Metodista de Piracicaba - Campus de Taquaral, 2005.

TEUBNER, Gunther. Global Bukowina: Legal Pluralism in the World Society. In: Gunther Teubner (ed.) Global law without state. Great Britain: Datmouth Publishing Company Limited, 2003.

TEUBNER, Gunther. Fragmentos constitucionais: constitucionalismo social na globalização. São Paulo: Saraiva, 2016.

THORNHILL, Chris. A Sociology of Transnational Constitutions: Social Foundations of the PostNational Legal Structure. Cambridge University Press. 2016.

KELSEN, Hans. Teoria Pura do Direito. 7. Ed. São Paulo: Martins Fontes, 2006.

WEISS, Edith Brown. The emerging international system and sustainable development. International Review for Environmental Strategies, v. 1, n. 1, p. 9-15, 2000.

WINTER, Gerd. Desenvolvimento sustentável, OGM e responsabilidade civil na União Europeia. Campinas, São Paulo: Milennium, 2009. 


\section{COMO FAZER REFERÊNCIA AO ARTIGO (ABNT):}

ROCHA, Leonel Severo; OLIVEIRA, Julia Francieli Neves de. O manifesto da transconstitucionalidade para preservação do meio ambiente. Revista Eletrônica do Curso de Direito da UFSM, Santa Maria, RS, v. 14, n. 3, e31955, set./dez. 2019. ISSN 1981-3694. DOI: http://dx.doi.org/10.5902/1981369431955. Disponível em: https: //periodicos.ufsm.br/revistadireito/article/view/31955 Acesso em: dia mês. ano.

\section{Direitos autorais 2019 Revista Eletrônica do Curso de Direito da UFSM}

Editores responsáveis: Rafael Santos de Oliveira e Angela Araujo da Silveira Espindola

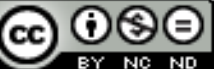

Esta obra está licenciada com uma Licença Creative Commons Atribuição-NãoComercial-SemDerivações 4.0 Internacional.

\section{SOBRE OS AUTORES}

\section{LEONEL SEVERo Rocha}

Possui graduação em Ciências Jurídicas e Sociais pela Universidade Federal de Santa Maria (1979), Mestrado em Direito pela Universidade Federal de Santa Catarina (1982), Doutorado pela Ecole des Hautes Etudes en Sciences Sociales de Paris (1989), Revalidado como Doutor na área do Direito, pela UFSC, em 13/02/2003, conforme processo 23080.025472/2002-06 e Resolução n.01/CNE/2001 ) e Pós-doutorado em Sociologia do Direito pela Universita degli Studi di Lecce - Itália. Atualmente é Professor Titular da Universidade do Vale do Rio dos Sinos e Coordenador Executivo (2012-2018) do Programa de PósGraduação em Direito (Mestrado e Doutorado, Capes 6), bem como é Professor do PPGD da Universidade Regional Integrada do Alto Uruguai (URI), Professor Visitante da Furb, e Professor Visitante da Faculté de Droit da Universidade de Paris 1. Membro pesquisador 1 do CNPq. Representante Titular da Área do Direito no CNPq-2016-2019.Preside a Comissão de Direito do PROEX-Unisinos-2012-2018. Consultor da Capes e da Fapergs. Vice-Presidente da região Sul do CONPEDI.Tem experiência na área de Direito, com ênfase em Teoria Geral do Direito, trabalhando principalmente os seguintes temas: Teoria dos Sistemas Sociais, Democracia e Teoria do Direito, tendo orientado até o momento 191 Dissertações, Teses e Supervisões de Pós-doutorado. Professor Leonel has an undergraduate degree from Law and Social Sciences at the Federal University of Santa Maria (1979). He has a Master degree on Law from the Federal University of Santa Catarina (1982), a Doctor degree from École des Hautes Etudes en Sciences Sociales de Paris (1989) and a Post-doc from the Universita degli Studi di Lecce. Currently he is a full Professor and Executive Coordinator of Postgraduate Programme in Law at the Universidade do Vale do Rio dos Sinos (Master and Doctor degree, Capes 6), and full Professor at the Universidade Regional Integrada do Alto Uruguai (URI), He is also a CNPq researcher. His main research interests concern Law, focusing on its General Theory, the Social Systems Theory and the Law Theory.

\section{JULIA FRANCIELI NeVES de SCHERBAUM}

Doutora no Programa de Pós-Graduação em Direito Público da UNISINOS, bolsista taxa PROEX (2016/2019). Realizou doutorado Sanduíche no Exterior na École de Droit de la Sorbonne Université Paris 1 - Panthéon- Sorbonne (2018). Participou do curso de extensão Universitária em Harvard Law Brazilian Association Legal Symposium, Democracia no séc. XXI (2018). Participou do curso de extensão Universitária na Instituição Berkeley Law University Of California, de Introduction to Fundamentals of U.S. Law (2017). Integrante do grupo de Pesquisa Teoria do Direito, da Universidade do Vale do Rio dos Sinos (UNISINOS), a pesquisa trata das contribuições realizadas pelos principais expoentes da teoria dos sistemas autopoiéticos para a renovação do Direito; enfatizando as relações entre a Democracia e o Direito nos processos de Diferenciação social nas constituições da América Latina. Este projeto está em andamento (2014). Mestre no Programa de Pós-Graduação Stricto Sensu em Direito da Universidade Regional Integrada do Alto Uruguai e das Missões (URI), Campus Santo Ângelo. Bolsista taxa CAPES/PROSUP (2013/2015). Integrante do Projeto de Pesquisa PROCAD/CAPES/Casadinho UNISINOS e URI, que investiga Cidadania e Direitos Culturais: a protecão dos direitos de minorias nos tribunais brasileiros, estudos sob a ótica do constitucionalismo contemporâneo e da teoria da complexidade de Edgar Morin, ambos vinculados ao referido mestrado. Este projeto está concluído (2013/2015). Pós-graduada Lato Sensu em Direito Processual Civil, na Universidade Anhanguera Uniderp (2012/ 2014). Graduada em Direito pela Universidade Regional Integrada do Alto Uruguai e das Missões. Bolsista integral PROUNI (2006/2011). Formada no Curso Normal - Magistério, Colégio Cenecista Sepé Tiaraju de Santo Ângelo (2005). Professora visitante na École de Droit de la Sorbonne Université Paris 1 - Panthéon- Sorbonne. Palestrante. Autora dos livros ?Afetividade no Direito de Família? (JURUÀ, 2018) e também do livro: CONSTITUCIONALIZAÇ̃̃O E A DEMOCRATIZAÇÃO DOS DIREITOS SOCIAIS DO TRABALHO NO BRASIL E FRANÇA (prelo, Ed. Appris). Advogada atua em Direito do Trabalho 